\title{
Conceptual Changes of Students in Thermodynamics in Physical Chemistry Course through the Implementation of Blended Learning
}

\author{
*Afadil, Sitti Rahmawati \& Suherman \\ Program Studi Pendidikan Kimia/FKIP - Universitas Tadulako, Palu - Indonesia 94119 \\ Received 22 June 2021, Revised 22 July 2021, Accepted 16 August 2021 \\ doi: 10.22487/j24775185.2021.v10.i3.pp174-181
}

\begin{abstract}
This study aims to determine the conceptual changes of students after participating in learning with a blended learning approach on Thermodynamics material. This research is a pre-experimental (pre-experimental design) with a Group PretestPostest Design. The blended learning approach is applied using the Problem Based Learning model. The research sample was Class C Odd Semester 2019/2020 students, with 34 students who programmed Physical Chemistry courses. The instrument used is a two-tier multiple-choice test that includes concepts in Thermodynamics material equipped with a valid CRI. The blended learning approach is one approach that can be used that facilitates student activities in utilizing ICT through the delivery of materials, discussion of task complete within in the search for teaching materials on Thermodynamics material. The results showed that misconceptions still occur in every concept of Thermodynamics. The average reduction of misconceptions (MC) is $11.2 \%$, the increase in the number of students to know concept (KC) classically is $19.2 \%$, and the decrease in the number of students unknowing concepts (UKC) is classically $8.1 \%$. Students' conceptual changes to the material of Thermodynamics are still low. Students are required to understand well the material's content related to basic concepts, mathematical equations (formulas), and the applicative forms of concepts in everyday life by the characteristics of the thermodynamic material.
\end{abstract}

Keywords: Conceptual change, misconceptions, thermodynamics, blended learning

\section{Introduction}

Concepts are generalizations and abstractions of facts and events that help understand the world around them (Dahar, 2011; Ibrahim, 2012). Conception develops a concept within a person (Suyono \& Hariyanto, 2011). Based on their understanding of a concept, a person can be grouped into three, namely people to knowing concept (KC), unknowing concept (UKC), and misconceptions (MC). The misconception is a discrepancy between students' understanding of concepts with scientific knowledge formulated by scientists in their fields (Vrabec \& Prokša, 2016). Conceptual change is changing the meaning of the existing conception towards a more scientific conception (Redhana et al., 2017). A student's conception results from his interaction with a concept that can lead to misconceptions if misinterpreted.

The phenomenon of misconceptions in students, students, teachers, lecturers, or anyone else should not be allowed because the occurrence of misconceptions in the initial concept will be a barrier to the ability of the following academic process (Metin, 2011; Erman, 2017). Posner (in Kaya \& Geban, 2012) suggests the conditions that must be met so that students' misconceptions can be changed, namely: (1) there must be dissatisfaction with existing concepts; (2) the new concept must be understandable; (3) the new concept must make sense; (4) the new concept must be practical or useful. Once these conditions have been met, students can experience a conceptual change.

Misconceptions require greater attention in learning chemistry. The occurrence of student misconceptions on chemical concepts because in chemistry courses, there are concepts that are not easy to understand unless they are related to something from everyday experience. According to Afadil et al. (2017), a complete and in-depth understanding of concepts needs to be introduced to students to improve thinking skills and knowledge of chemical concepts. Therefore, determining students' conceptions becomes very

${ }^{*}$ Correspondence:

Afadil

e-mail: afadil@untad.ac.id

(c) 2021 the Author(s) retain the copyright of this article. This article is published under the terms of the Creative Commons Attribution-NonCommercial-ShareAlike 4.0 International, which permits unrestricted non-commercial use, distribution, and reproduction in any medium, provided the original work is properly cited. 
important, and further learning models are sought to prevent and reduce them.

Various research results found that misconceptions have occurred in several chemical concepts such as acid-base (Metin, 2011), stoichiometric (Nilawati et al., 2017), basic concepts in chemistry (Härmälä-Braskén et al., 2020), organic chemistry (O'Dwyer \& Childs, 2017), covalent bonds (Erman, 2017), the reaction rate (Sunyono, 2014; Kaya \& Geban, 2012), colligative properties (Sunyono, 2014), carbohydrates (Milenković et al., 2016), Acid-Base Concept (Pikoli, 2020), and chemical kinetics (Afadil \& Diah, 2020). Several facts show that there is still an assumption that chemistry subjects in school are complex subjects to learn (Adesoji et al., 2017; Sanchez, 2017). The cause of this difficulty is because many chemistry subject matter is abstract (Olakanmi, 2017; O'Dwyer \& Childs, 2017), it is challenging to distinguish macroscopic and microscopic concepts (Hasanah et al., 2020), and Effendy (2014) explains that the fundamental problems in chemistry learning that cause misconceptions in students today are (1) the acquisition of an incomplete understanding of chemistry by students, and (2) the non-optimal development of higher-order thinking skills, (HOTS).

Various efforts were made related to efforts to reduce student misconceptions, including Afadil \& Diah (2018) through the development of a science philosophy-oriented learning device that was developed to minimize the misunderstandings of SMA Negeri 1 Palu students for salt hydrolysis material from an average of $53.9 \%$ to $19,6 \%$ or decreased by an average of $34.3 \%$. Afadil \& Diah (2019), by applying the PS-TRILOGY learning model oriented to local wisdom, were able to reduce student misconceptions (MK) on solution chemistry by $12.2 \%$; able to increase the knowledge of concepts (TK) of students by $26.9 \%$; and able to reduce do not know the concept (TTK) of students by $16.6 \%$. From the results of these studies, it appears that there are still chemical concepts that are responded to by misconceptions.

Misconceptions must be attempted to be corrected with conceptual changes (Dahar, 2011). Based on the theory of conceptual evolution, cognitive conflict is one of the effective strategies to facilitate conceptual change. Competition can be caused by providing an anomaly or event contrary to the student's mind. This conflict will result in students not assimilating their knowledge of new concepts (knowledge). By itself, there will be a process of concept reconstruction due to events that challenge students to think more and question why their initial thoughts were not correct (Mumu et al., 2017). According to Atmacasoy \& Aksu (2018) providing opportunities for various student characteristics causes independent, sustainable, and lifelong learning efforts to be more effective, efficient, and attractive. One approach that can be taken to respond to technological and information developments is through a blended learning approach.

Blended learning or mixed learning is a learning approach that combines harmony, ously, structured, and system between the advantages of face-to-face and online learning. Mixed learning is becoming popular and the rapid development of Information and Communication Technology (ICT), namely the combination of internet networks and computing capabilities (IoT), enables more efficient and effective learning in developing student learning outcomes. According to Allen et al. (2007), the use of ICT in the learning process must be given proportional limits. The face-to-face and online learning implementation modes are integrated and systematically oriented to learning outcomes.

One of the efforts to provide information to lecturers and students about which components need improvement is to analyze changes in students' conceptions of study material in the learning. In addition, it can provide signs for lecturers to be aware of things that allow misconceptions to occur before and during the learning process. Through the analysis results, lecturers look for solutions to correct students' misconceptions. This is influenced by the causes of misunderstandings experienced by students. Therefore, lecturers are expected to find and choose methods and strategies for correcting misconceptions suitable for the situations and conditions faced by students. Based on the change in conception, the lecturer can determine the appropriate learning for a particular material as a characteristic. When handling student misconceptions comprehensively and specifically, it is hoped that students will have stability in understanding the concept of thermodynamics.

\section{Methods}

This research is a pre-experimental (preexperimental design) with a one-group pretestpostest design. In general, according to Fraenkel \& Wallen (2009). The first step is to measure the pretest, then be treated and end with the post-test. The research sample is Class C odd Semester $2019 / 2020$ as many as 34 students with 11 males and 23 females who program physical chemistry courses. The place of research is at the Chemistry Education Study Program, FKIP Tadulako University. The online learning media used is the Learning Management System (LMS) developed by FKIP Tadulako University. Learning is carried out using a problem-based (PBL) model through a blended learning approach. Learning materials (lesson plans, worksheets, textbooks, and instruments to determine changes in conception) that have been developed based on verification from a team of experts. The test result data obtained from the student's conception test is used as raw data to determine the pattern of shifting students' conceptions. The instrument used is a two-tier 
multiple-choice test that includes concepts in chemical kinetics, equipped with a Certainty of Response Index (CRI). CRI is a technique to measure a person's misconceptions by measuring a person's level of confidence or certainty in answering each question given. According to Hasan et al. (1999), CRI is based on a fixed scale; in this study, the scale used is a scale of six (0-5), as presented in Table 1.

Table 1. Rating and Category Conception Students

\begin{tabular}{|c|c|}
\hline Rating & Category \\
\hline 0 & Guessed Answer: If you answered about \\
\hline 1 & $\begin{array}{l}\text { Almost a guess: If in answering questions } \\
\text { guesses element percentage between } 75 \% \text { - } \\
99 \% \text { or almost guess. }\end{array}$ \\
\hline 2 & $\begin{array}{l}\text { Not Sure: If in answering questions, } \\
\text { percentage guesses element between } 50 \% \text { - } \\
74 \% \text { or unsure. }\end{array}$ \\
\hline 3 & $\begin{array}{l}\text { Sure: If in answering questions, percentage } \\
\text { guesses element between } 25 \%-49 \% \text { or } \\
\text { confident. }\end{array}$ \\
\hline 4 & $\begin{array}{l}\text { Almost Certain: If the answer the riddle } \\
\text { element percentage between } 1 \% \text { and } 24 \% \text {, } \\
\text { or nearly specific. }\end{array}$ \\
\hline 5 & $\begin{array}{l}\text { Specific: If in answering questions is no } \\
\text { element of guesswork at all }(0 \%) \text { or } \\
\text { definitely. }\end{array}$ \\
\hline
\end{tabular}

The decision matrix for an individual student and a given question was analyzed using the matrix in Table 2. Matrix was derived from the student's answer based on combinations of correct or wrong answers and of low or high CR.

Table 2. Decision matrix for an individual student based on combinations of correct or wrong answers and low or high CRI

\begin{tabular}{|c|c|c|}
\hline $\begin{array}{l}\text { Criteria } \\
\text { Answer }\end{array}$ & $\begin{array}{c}\text { Low CRI }(< \\
2.5)\end{array}$ & High CRI $(>2.5)$ \\
\hline \multirow{2}{*}{$\begin{array}{l}\text { Correct } \\
\text { answer }\end{array}$} & \multirow{2}{*}{$\begin{array}{l}\text { Correct answer } \\
\text { and low CRI } \\
\text { Lack of } \\
\text { knowledge } \\
\text { (lucky guess) }\end{array}$} & $\begin{array}{l}\text { Right answer and } \\
\text { high CRI }\end{array}$ \\
\hline & & $\begin{array}{l}\text { Knowledge of } \\
\text { correct concepts }\end{array}$ \\
\hline \multirow{2}{*}{$\begin{array}{l}\text { Wrong } \\
\text { answer }\end{array}$} & \multirow{2}{*}{$\begin{array}{l}\text { Wrong answer } \\
\text { and low CRI } \\
\text { Lack of } \\
\text { knowledge }\end{array}$} & $\begin{array}{l}\text { Wrong answer and } \\
\text { high CRI }\end{array}$ \\
\hline & & Misconceptions \\
\hline
\end{tabular}

Identification of student conceptions is intended to determine the percentage of students who experience misconceptions about certain concepts. The percentage calculation is determined by the number of students who participate in delusions divided by the total number. Identifying misconceptions aims to determine which idea has a higher misconception among other concepts in learning material. Each group was determined by the average CRI score of students' correct answers (CRIC), the average CRI of students' wrong answers (CRIW), and the fraction of students who responded correctly $(\mathrm{Fb})$. The CRIC score is obtained from the number of CRI students who answered rightly divided by the number of students who answered correctly. The CRIW score is obtained from the number of CRI students who answered incorrectly divided by the total number of students who answered incorrectly.

Meanwhile, $\mathrm{Fb}$ was obtained from the total number of students who answered correctly, divided by $100 \%$ (Nakhleh, 1992). The data were then analyzed using tables, percentages, and graphs. The results of data analysis are discussed narratively by comparing the results with the theory.

\section{Results and Discussion}

Thermodynamics material taught consists of concepts, namely: (1) work, (2) heat, (3) isobaric, (4) adiabatic, (5) isochoric, (6) heat capacity, (7) First Law of Thermodynamics, (8) enthalpy reaction, and (9) isothermal. The distribution of students' conceptions related to Thermodynamics was measured using a concept change test declared valid by the validator team. The tracking of changes in students' conceptions was carried out 2 (two) times, namely through a pretest and post-test in the form of a two-tier multiple-choice test that included concepts in Thermodynamics material equipped with CRI. The grouping of students' conceptions based on the results of the pretest in the categories of knowing concept (KC), unknowing concept (UKC), and misconceptions (MC) on each idea that represents chemical kinetics material is presented in Figure 1

Based on the data in Figures 1 and 2, it can explain that each concept was responded to by students in the UKC and MC categories on average. Of the nine concepts tested, all caused students to experience misconceptions. Most of the students (> $50 \%$ ) were in the MC category, namely the First Law of Thermodynamics concept. While other ideas are more dominant, students respond with the UKC category. $14.4 \%(\mathrm{KC})$ students already have good initial knowledge regarding Thermodynamics material. The initial knowledge was obtained from understanding the Basic Chemistry course, which discussed Thermochemistry and other learning resources. According to Schunk (2011), students prior knowledge contributes to forming or understanding internally knowledge obtained through personal interaction by asking their questions (self-questioning). 


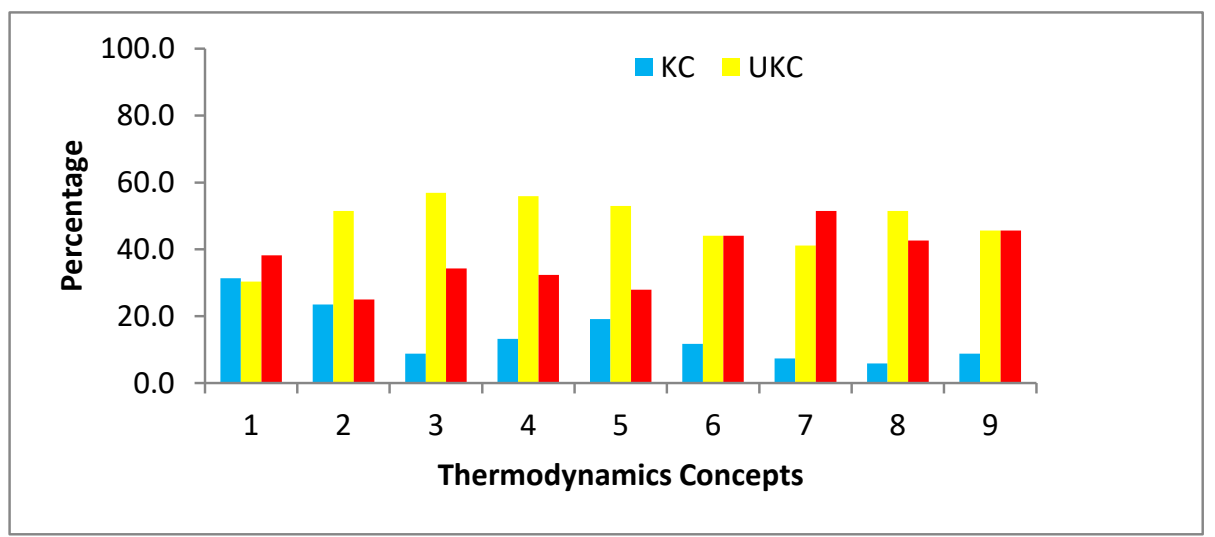

Figure 1. Comparison of the percentage of class $\mathrm{C}$ students of $\mathrm{KC}, \mathrm{UKC}$, and $\mathrm{MC}$ in the pretest thermodynamics material

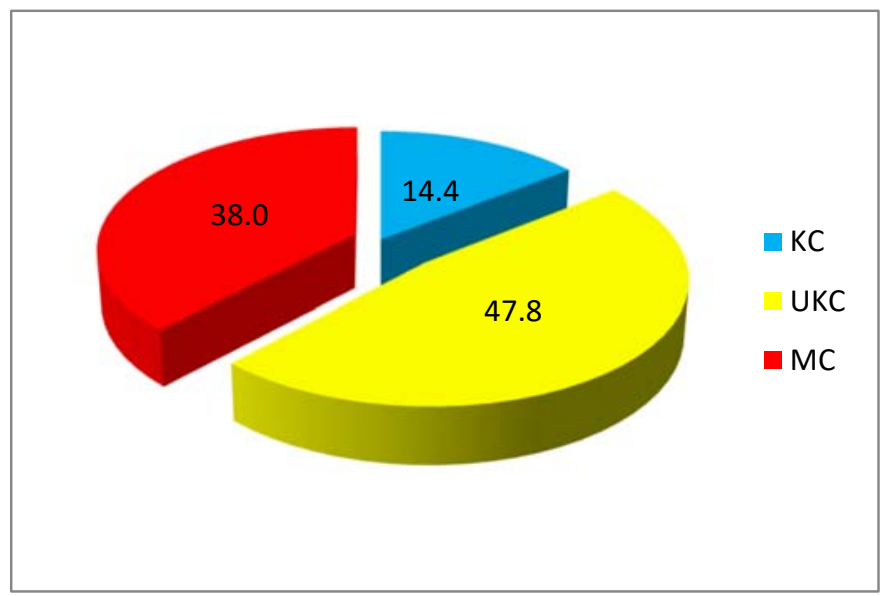

Figure 2. Average percentage of class $\mathrm{C}$ students of KC, UKC, and $\mathrm{MC}$ in the implementation of the thermodynamic material pretest

Identification of student conceptions in groups is used to determine the concept suspected of having the most substantial misconception from the nine (9) concepts tested. Identification is based on CRIC, CRIW, and $\mathrm{Fb}$ data for each test item representing the concepts in the Thermodynamics material. CRIC, CRIW, and $\mathrm{Fb}$ data calculated from the pretest results are presented in Figure 3.

According to Hasan et al. (1999), misconceptions occur and have a solid classical impact if the average CRIW value $(2.5<$ CRIW 5.0) and $\mathrm{FB}<0.5$. Based on the CRIW and FB values in Figure 3, it appears that there are students who experience misconceptions for every concept tested, but the impact is not classically strong. From the results of the conceptual analysis, students are more dominant in the UKC category, namely 5 of 9 concepts $(55.6 \%)$ students who respond $>50 \%$, while for the MC category, only 1 of 9 ideas $(11.1 \%)$ replies $>50 \%$. This shows that the concepts taught in the Thermodynamics material have an easier chance of being converted into Kindergarten. Changing someone from $\mathrm{UKC}$ to $\mathrm{KC}$ is more accessible than changing $\mathrm{MC}$ to $\mathrm{KC}$. There is difficulty changing one's misconceptions (misconceptions) into scientifically acceptable conceptions (actual concepts); someone even grafts their new knowledge onto a conceptually incorrect basis. After learning with a blended learning approach on Thermodynamics material based on the semester lesson plan (RPS), we get a picture of changes in the conception of Class $\mathrm{C}$ students according to Figure 4.

Based on Figures 4 and 5, it appears that, on average, each concept is still responded to by students with misconceptions but experiencing conceptual changes compared to the preconception/pretest. It seems that all of the nine ideas tested still cause students to experience misunderstandings. However, the nine concepts were responded to by misconceptions < 50\% experienced reduction but could not be eliminated. The identification results are based on CRIC, $\mathrm{CRIW}$, and $\mathrm{Fb}$ data for each test item representing the concepts in the Thermodynamics material presented in Figure 6. 


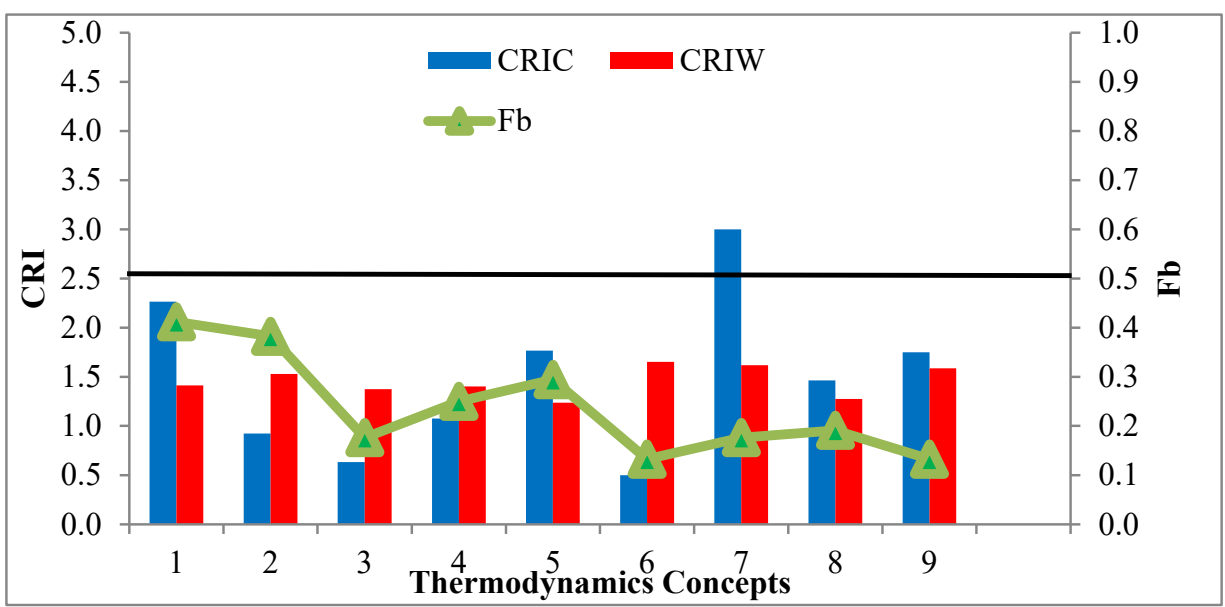

Figure 4. Comparison graph of CRIC, CRIW, and Fb pretest class $\mathrm{C}$ students for thermodynamics

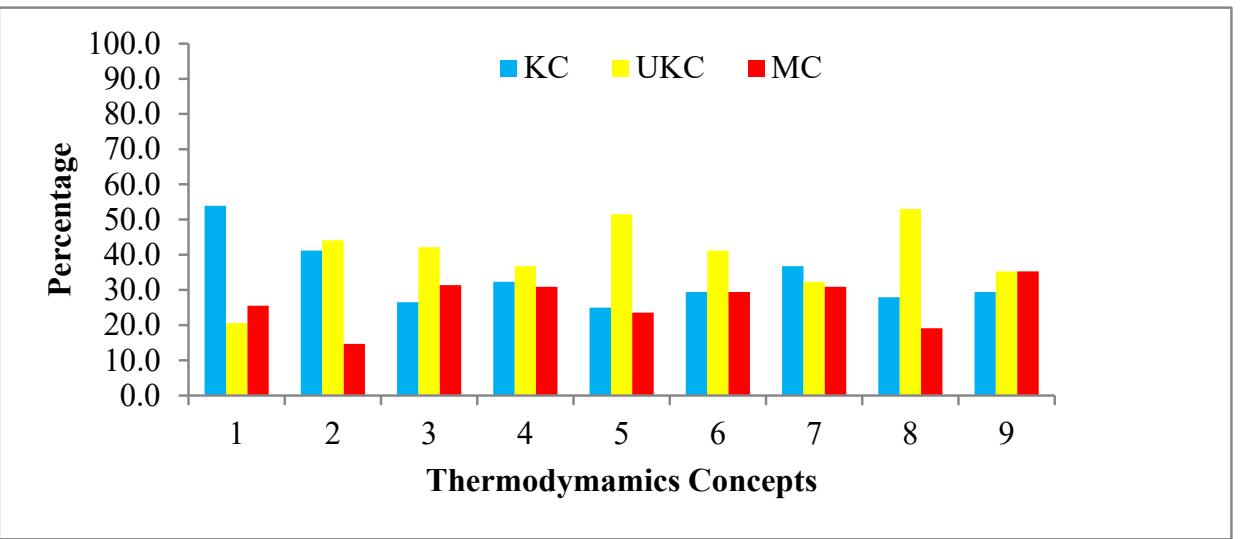

Figure 5. Comparison of the percentage of class $\mathrm{C}$ students of KC, UKC, and MC in the posttest implementation for thermodynamics materials

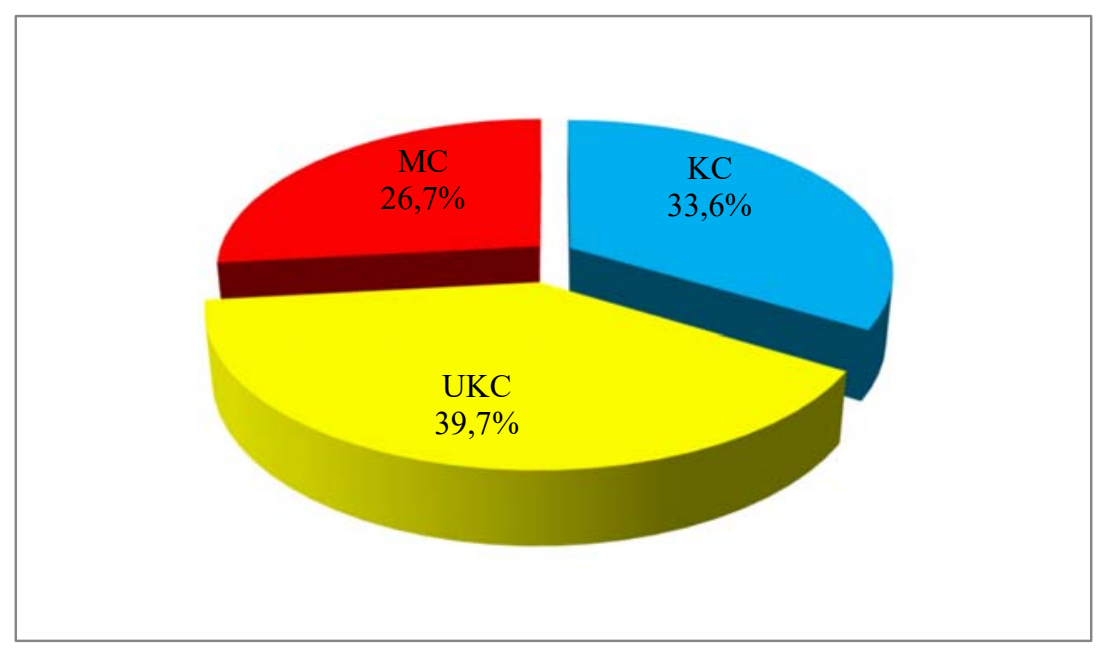

Figure 6. Average percentage of class $\mathrm{C}$ students of KC, UKC, and MC in the posttest implementation of thermodynamics materials 


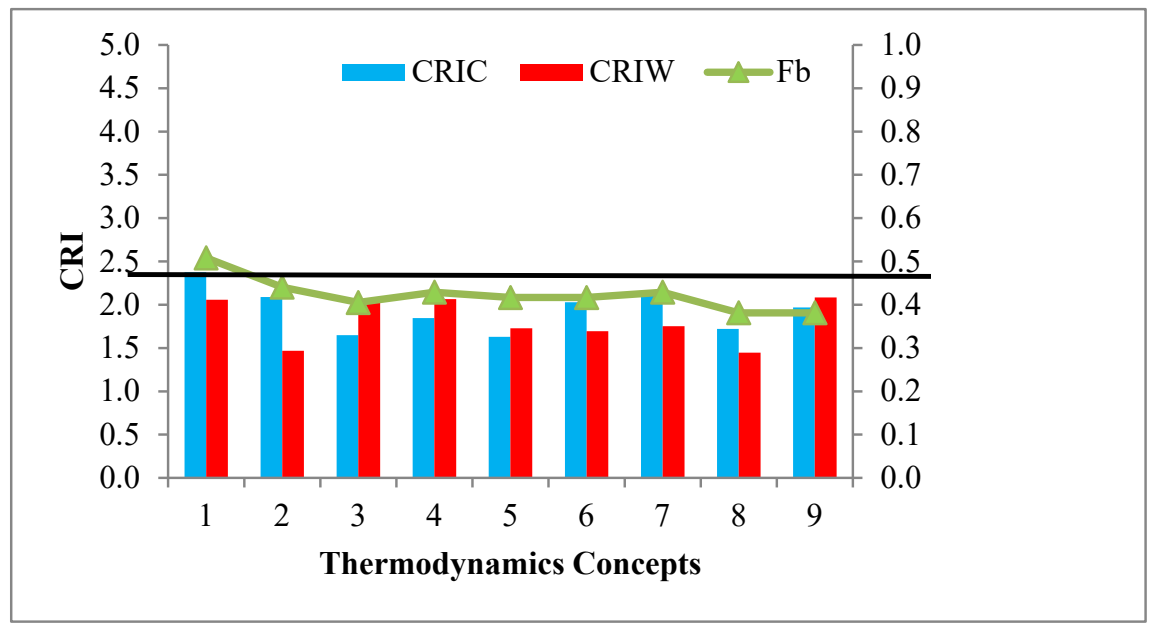

Figure 7. Comparison graph of CRIC, CRIW, and $\mathrm{Fb}$ posttest for class $\mathrm{C}$ students in thermodynamics

Comparison of student concepts on learning approach from the pretest and post-test Thermodynamics material through a blended results can be seen in Table 3 .

Table 3. Comparison of percentage of misconception (MC), knowing concept (KC), and unknowing concept (UKC) of students on pretest and post-test of thermodynamics material

\begin{tabular}{|c|c|c|c|c|c|c|c|c|c|c|}
\hline \multirow{2}{*}{ No } & \multirow{2}{*}{ Concepts } & \multicolumn{3}{|c|}{ MC (\%) } & \multicolumn{3}{|c|}{ KC (\%) } & \multicolumn{3}{|c|}{ UKC (\%) } \\
\hline & & Pretest & Posttest & Reduct & Pretest & Posttest & Ride & Pretest & Posttest & Reduct \\
\hline 1 & Effort & 38.2 & 25.5 & 12.7 & 31.4 & 53.9 & 22.5 & 30.4 & 20.6 & 9.8 \\
\hline 2 & Heat & 25.0 & 14.7 & 10.3 & 23.5 & 41.2 & 17.6 & 51.5 & 44.1 & 7.4 \\
\hline 3 & isobaric & 34.3 & 31.4 & 2.9 & 8.8 & 26.5 & 17.6 & 56.9 & 42.2 & 14.7 \\
\hline 4 & Adiabatic & 32.4 & 30.9 & 1.5 & 13.2 & 32.4 & 19.1 & 55.9 & 36.8 & 19.1 \\
\hline 5 & Isochoric & 27.9 & 23.5 & 4.4 & 19.1 & 25.0 & 5.9 & 52.9 & 51.5 & 1.5 \\
\hline 6 & $\begin{array}{l}\text { heat } \\
\text { capacity }\end{array}$ & 44.1 & 29.4 & 14.7 & 11.8 & 29.4 & 17.6 & 44.1 & 41.2 & 2.9 \\
\hline 7 & $\begin{array}{l}\text { 1st Law } \\
\text { of } \\
\text { Thermod } \\
\text { ynamics }\end{array}$ & 51.5 & 30.9 & 20.6 & 7.4 & 36.8 & 29.4 & 41.2 & 32.4 & 8.8 \\
\hline 8 & $\begin{array}{l}\text { Reaction } \\
\text { Enthalpy }\end{array}$ & 42.6 & 19.1 & 23.5 & 5.9 & 27.9 & 22.1 & 51.5 & 52.9 & -1.5 \\
\hline 9 & $\begin{array}{l}\text { isotherma } \\
\text { l }\end{array}$ & 45.6 & 35.3 & 10.3 & 8.8 & 29.4 & 20.6 & 45.6 & 35.3 & 10.3 \\
\hline 10 & Average & 38.0 & 26.7 & 11.2 & 14.4 & 33.6 & 19.2 & 47.8 & 39.7 & 8.1 \\
\hline
\end{tabular}

Pretest scores are used to determine students' initial conceptions, while post-test scores obtained by students describe student learning outcomes after attending lectures through a blended learning approach. The results research conducted by Dziuban et al. (2004) found the blended learning approach has the potential to improve student learning outcomes and also reduce dropout rates compared to fully online learning; in addition, it was also found that the learning model with the blended learning approach is better than face-toface learning.
Based on Table 3, the conceptual changes that occurred after the application of the blended learning approach only had a minor impact, namely: the average reduction in the $\mathrm{MC}$ was $11.2 \%$, the increase in the number of students to classical KC is $19.2 \%$, and the decrease in the number of students who were classically UKC as much as $8.1 \%$. Based on these results, the application of the blended learning approach gives positive results in changing students' conceptions of the Thermodynamics material. However, there are still misconceptions about each of these concepts. This shows that lecturers still need to pay attention 
to the characteristics of study materials in applying an approach/method/learning model. Regarding this condition, according to Allen et al. (2007), in using the blended learning approach, both in the perspective of lecturers and students, there are several good practice models. Study programs can apply various mixed learning models, such as rotation models, flex models, self-blend models, enriched virtual models, or flipped learning, but what must be considered is the suitability of the learning environment and adapting to the characteristics of the learning material.

Based on the results obtained, it appears that, in general, students still experience misconceptions about each concept in the Thermodynamics material. According to Dahar (2011), misconceptions are possible due to student interactions with lecturers or textbooks. The process of forming misunderstanding in learning, especially at the primary level, is as follows: (1) a person tends to base his thinking on things that appear in a problem situation, (2) a person only pays attention to certain aspects in a situation, is more likely to interpret a phenomenon. And in terms of the absolute nature of things, not in terms of interactions between the elements of a system, (3) A person is more likely to pay attention to change than a stationary situation, (4) his way of thinking tends to follow a linear causal sequence, (5) A person has various connotations that more inclusive and global, and (6) a person often uses different ideas to interpret situations that scientists use the same way.

The occurrence of misconceptions can also be caused by ideas that arise from the minds of personal students. These ideas are generally less scientific, and if the lecturer does not try to see the ideas that students have before introducing the concept, it will result in misconceptions. So far, the learning of physical chemistry courses has been carried out offline with material because it contains basic concepts, many equations or formulas, and practicum. The material's content is basic concepts, mathematical equations (formulas), and the applicative forms of ideas in everyday life. The results of this study illustrate that lecturers and students still need to make more effective efforts to improve their understanding of concepts. Efforts should be made continuously to improve knowledge content. Prospective chemistry teachers must acquire good chemistry knowledge to transfer the correct expertise to students. According to Fatokun (2016), developing a learning approach involving new ideas and discussions will help students identify and reduce their misconceptions.

\section{Conclusions}

Responding to the development of Information and Technology in learning, various effective ways to improve students' conceptual understanding must be implemented. Students need to obtain the correct concept in each learning material to correct misconceptions in other materials. Thermodynamics is one of the learning materials that students often respond to with misunderstanding. The blended learning approach is one approach that can be used that facilitates student activities in utilizing ICT through the delivery of materials, discussion of task completion, and training in the search for teaching materials on Thermodynamics material. The results showed that misconceptions still occur in every concept of Thermodynamics. The average misconception reduction (MC) is $11.2 \%$, the increase in the number of students to know concepts (KC) classically is $19.2 \%$, and the decrease in the number of students of unknowing concepts (UKC) is classically is $8.1 \%$. Students' conceptual changes to the Thermodynamics material have improved concept understanding.

\section{Acknowledgment}

Thank you to the Faculty of Teacher Training and Education, Especially the Chemistry Education Study Program, for the assistance in providing facilities and infrastructure to implement this research.

\section{References}

Adesoji, F. A., Omilani, N. A., \& Dada, S. O. (2017). A comparison of perceived and actual; Students' learning difficulties in physical chemistry. International Journal of Brain and Cognitive Sciences, 6(1), 1-8.

Afadil, \& Diah, A. W. (2018). Effectiveness of learning materials with science philosophy oriented to reduce misconception of students on chemistry. Proceeding of The First Indonesian Communication Forum of Teacher Training and Education Faculty Leaders International Conference on Education 2017 (pp 192-196). Netherlands: Atlantis Press.

Afadil, \& Diah, A. W. (2019). Analisis perubahan konseptual mahasiswa pada materi kimia larutan melalui penerapan model pembelajaran $p s$-trilogi berorientasi kearifan lokal. Jurnal Jejaring Matematika dan Sains, 1(1), 22-29.

Afadil, \& Diah, A. W. (2020). Conceptual change of prospective chemistry teachers through the implementation of ps-trilogi learning model on chemical kinetics. International Journal of Advanced Science and Technology, 29(5s), 777783.

Afadil., Suyono, S., \& Poedjiastoeti, S. (2017). Effectiveness of learning based problem solving with aspect ontology, epistemology, axiology to increase critical thinking ability and understanding thermochemical concept of students. International Journal of Active Learning, 1(2), 66-74.

Allen, I. E., Seaman, J., \& Garrett, R. (2007). Blending in the extent and promise. USA: Sloan$\mathrm{C}^{\mathrm{TM}}$.

Atmacasoy, A., \& Aksu, M. (2018). Blended learning at pre-service teacher education in 
Turkey: A systematic review. Education and Information Technologies, 23(May), 2399-2422.

Dahar, R. W. (2011). Teori-teori belajar. Jakarta: Ditjen Dikti-P2LPTK.

Dziuban, C., Hartman, J., Juge, J., Moskal, P., \& Sorg, S. (2004)., Blended learning: Online learning enters the mainstream. In C. J. Bonk \& C. Graham, (Eds.), Handbook of Blended Learning Environments: Global Perspectives (pp 195-208). San Fransisko: Pfeiffer.

Effendy. (2014). Pembelajaran kimia secara mendasar untuk menjawab tantangan dan memenuhi harapan kurikulum 2013. Prosiding Seminar Nasional Kimia Universitas dan Pembelajarannya (SNKP) 2015 (pp 1-11). Malang: Jurusan Kimia Fakultas Matematika dan Pengetahuan Alam Universitas Negeri Malang.

Erman, E. (2017). Factors contributing to students' misconceptions in learning covalent bonds. Journal of Research in Science Teaching, 54(4), 520-537.

Fatokun, K. V. F. (2016). Instructional misconceptions of prospective chemistry teachers in chemical bonding. International Journal of Science and Technology Education Research, 7(2), 18-24.

Fraenkel, J. R., \& Wallen, N. E., (2009). How to design and evaluate research in education 7 th $\mathrm{ed}$. New York: McGraw-Hill Companies.

Härmälä-Braskén, A. S., Hemmi, K., \& Kurtén, B. (2020). Misconceptions in chemistry among Finnish prospective primary school teachers-a long-term study. International Journal of Science Education, 42(9), 1447-1464.

Hasanah, S., Purwoko, A. A., \& Hakim, A. (2020). The effect of guided inquiry learning model on chemistry learning outcomes. Journal of Science and Science Education, 1(1), 15-20.

Hasan, S., Bagayoko, D., Kelley, E. L. (1999). Misconceptions and the certainty of response index (CRI). Physic Education, 34(5), 294-299.

Ibrahim, M. (2012). Konsep miskonsepsi dan pembelajarannya. Surabaya: Unesa University Press.

Kaya, E., \& Geban, O. (2012). Facilitating conceptual change in rate of reaction concept's using conceptual change oriented instruction. Education and Science, 37(163), 216-225.

Metin, M. (2011). Effects of teaching material based on 5E model removed pre-Service teachers' misconceptions about acids-bases. Bulgarian Journal of Science and Education Policy (BJSEP), 5(2), 274-302.

Milenković, D. D., Hrin, T. N., Segedinac, M. D., \& Horvat, S. (2016). Development of a threetier test as a valid diagnostic tool for identification of misconceptions related to carbohydrates. Journal of Chemical Education, 93(9), 1514-1520.
Mumu, J., Rully, R. C. I., \& Tanujaya, B. (2017). Construction and reconstruction concept in mathematics instruction. Journal of Physics: Conference Series, 943012011.

Nakhleh, M. B. (1992). Why some students don't learn chemistry: Chemical misconceptions. Journal of Chemical Education, 69(3), 191-196.

Nilawati, P. A., Subandi., \& Utomo, Y. (2017). Keefektifan pembelajaran interkoneksi multipel representasi dalam mengurangi kesalahan konsep siswa pada materi stoikiometri. Jurnal Pendidikan: Teori, Penelitian, dan Pengembangan, 1(11), 2076-2082.

O'Dwyer, A., \& Childs, P. E. (2017). Who says organic chemistry is difficult? Exploring perspectives and perceptions. Eurasia Journal of Mathematics, Science and Technology Education, 13(7), 3599-3620

Olakanmi, E. E. (2017). The effects of a flipped classroom model of instruction on students' performance and attitudes towards chemistry. Journal of Science Education and Technology, 26(October), 127-137.

Pikoli, M. (2020). Using guided inquiry learning with multiple representations to reduce misconceptions of chemistry teacher candidates on acid-base concept. International Journal of Active Learning, 5(1), 1-10.

Redhana, I. W., Sudria, I. B. N., Hidayat, I., \& Merta, L. M. (2017). Identification of chemistry learning problems viewed from conceptual change model. Jurnal Pendidikan IPA Indonesia, 6(2), 356-364.

Sanchez, J. M. P. (2017). Integrated macro-microsymbolic approach in teaching secondary chemistry. Kimika, 28(2), 22-29.

Schunk, D. H. (2011). Learning theories: an educational perspective, 6th ed. Boston: Pearson.

Sunyono. (2014). Model pembelajaran berbasis multipel representasi dalam membangun model mental dan penguasaan konsep kimia dasar mahasiswa. Unpublished Master's Thesis. Surabaya: Pascasarjana Universitas Surabaya.

Suyono, \& Haryanto. (2011). Belajar dan pembelajaran. Bandung: PT. Remaja Rosada Karya.

Vrabec, M., \& Prokša, M. (2016). Identifying misconceptions related to chemical bonding concepts in the Slovak school system using the bonding representations inventory as a diagnostic tool. Journal of Chemical Education, 93(8), 1364-1370. 